\title{
Pengaruh Musik terhadap Peforma Sapi Perah FH Laktasi
}

\author{
D. N. Mutiasari'1, T. Akhdiat ${ }^{2}$, H. Permana ${ }^{2}$, N. Widjaja ${ }^{2, *}$ \\ ${ }^{1}$ Direktorat Ajudan Jendral Angkatan Darat Bandung \\ ${ }^{2} J u r u s a n$ Produksi Ternak Fakultas Peternakan Universitas Bandung Raya
}

\begin{abstract}
ABSTRAK
Penelitian bertujuan untuk mengetahui sejauh mana pengaruh musik terhadap konsumsi ransum, produksi susu, serta konversi pakan pada sapi perah FH laktasi. Metode Penelitian adalah eksperimen menggunakan Rancangan Acak Lengkap (RAL) dengan 4 perlakuan yaitu (M0) tanpa diperdengarkan musik, (M1) diperdengarkan musik tradisional sunda, (M2) diperdengarkan musik jazz, dan (M3) diperdengarkan musik klasik, setiap diperlakuan ulang sebanyak 5 kali. Perubah yang diamati yaitu konsumsi ransum, produksi susu, dan konversi ransum. Data dianalis dengan sidik ragam, apabila terdapat pengaruh perlakuan dilanjutkan dengan Uji Jarak Berganda Duncan's. Penelitian ini menyimpulkan bahwa musik berpengaruh terhadap peforma sapi perah FH laktasi, jenis musik klasik memberikan peforma yang optimal pada sapi perah FH laktasi.
\end{abstract}

Kata Kunci: Musik, Susu Sapi, Periode Laktasi

\section{The Effect of Music to Performance of Milk Cows FH in Lactation Period}

\section{ABSTRACT}

This research aimed to analyze the effect of music to feed consumption, milk production, and feed conversion in milk cows FH in lactation period. This research was experimental study using Complete Randomized Design (CRD) with 4 treatments consisted in M0 (without hearing music), M1 (hearing traditional music), M2 (hearing jazz music), and M3 (hearing classical music). Each treatments was replicated 5 times. Observed variables namely feed consumption, milk production, and feed conversion. Data were analyzed using variance, if there is a significant difference in treatments effects, it will be followed by Duncan's Multiple Test Area. Based on the results and discussion, there are two kinds of conclusions can be drawn as follows music contributes effects to the performance of milk cows FH in lactation period, classical music contributes the optimal performance of milk cows FH in lactation period.

Key words : Music, Milk Cows FH, Lactation Period

\section{PENDAHULUAN}

Sapi adalah salah satu ternak ruminansia yang populasinya tersebar luas di seluruh dunia, terutama pada daerah yang produksi pertaniannya memungkinkan. Penyebaran ternak ini lebih merata dibandingkan domba dan kambing namun demikian ternak sapi jarang ditemukan pada lingkungan yang ekstrim tidak bersahabat.

Sapi perah merupakan salah satu komoditi peternakan yang dapat mendukung pemenuhan kebutuhan akan bahan pangan bergizi tinggi. Pemeliharaan sapi perah beberapa tahun terakhir ini menunjukkan perkembangan yang pesat. Perkembangan ini senantiasa didorong oleh pemerintah agar swasembada susu tercapai secepatnya. Untuk pemenuhan permintaan masyarakat terhadap susu perlu diperhatikan hal-hal yang akan mempengaruhui produksi susu. Ada beberapa faktor yang mempengaruhi produksi sapi perah yaitu faktor dari dalam (internal) dan faktor dari luar (eksternal). Faktor dari dalam berpengaruh sebesar $30 \%$ dan luar $70 \%$ terhadap produksi susu sapi perah. Faktor lingkungan adalah faktor yang memberikan pengaruh cukup besar terhadap tingkat produksi. Di antara sekian banyak komponen, faktor

\footnotetext{
*Penulis Korespondensi: N. Widjaja

Alamat : Jl. Banten No. 11. Bandung, Jawa Barat 40272

E-mail : nalamsyahsw@gmail.com
}

lingkungan adalah yang paling nyata pengaruhnya terhadap sapi perah, terutama pada masa laktasi (Sudono dan Sutardi, 1969).

Faktor lingkungan dapat diklasifikasikan dalam dua komponen, yaitu abiotik (air, udara, tanah, sinar matahari, suhu, dan mineral) dan biotik (semua makhluk hidup di bumi, baik manusia, tumbuhan maupun hewan). Faktor lingkungan abiotik adalah faktor yang paling berperan sebagai menyebabkan stress fisiologis.

Adanya stress pada sapi ini bisa dikarenakan adanya gangguan yang berada di sekitar sapi tersebut. Gangguan yang berasal dari luar mengganggu hormon laktasi, bisa disebabkan oleh adanya beberapa gangguan terhadap kenyamanan sapi yaitu; seperti gangguan dari hewan lain, pemerahan terlalu awal, rasa sakit sewaktu akan diperah, dan iritasi pada puting susu sapi, hal tersebut dapat mengurangi jumlah produksi susu sapi.

Menurut Leanne (2001), menganalisa bahwa musik dapat mengurangi rasa stress pada sapi perah, sehingga musik yang menenangkan dapat meningkatkan produksi susu. Selain manusia, hewan pun dapat merasakan dampak dari diperdengarkan musik, karena dengan diperdengarkan musik pada sapi maka sapi akan merasa tenang dan nyaman. Kenyamanan yang diterima oleh sapi ini akan berdampak pada hormon yang akan mengeluarkan air susu yang lebih banyak. Hormon Oxyitocin yang 
Tabel 1. Rataan konsumsi ransum pada masing-masing perlakukan selama penelitian

\begin{tabular}{ccccc}
\hline \hline \multirow{2}{*}{ Ulangan } & \multicolumn{4}{c}{ Perlakuan } \\
\cline { 2 - 5 } & M0 & M1 & M2 & M3 \\
\cline { 2 - 5 } 1 & 37,87 & 38,70 & 37,70 & 38,77 \\
2 & 38,31 & 38,59 & 37,72 & 38,62 \\
3 & 38,21 & 38,62 & 37,66 & 38,59 \\
4 & 37,89 & 38,5 & 37,65 & 38,74 \\
5 & 37,79 & 38,61 & 37,53 & 193,3 \\
\hline Jumlah & 190,07 & 193,02 & 188,26 & 38,66 \\
\hline Rataan & 38,01 & 38,60 & 37,65 & \\
\hline
\end{tabular}

lebih banyak keluar pada saat sapi merasa nyaman pada saat pemerahan berlangsung dan sapi akan mengeluarkan air susunya. Penelitian yang dilakukan di University of Leicester bahwa dengan memberikan/mendengarkan musik pada sapi perah akan meningkatkan produksi susu sapi sebanyak 3\% bila dibandingkan dengan sapi yang tidak diperdengarkan musik.

\section{MATERI DAN METODE}

Penelitian ini dilaksanakan di Peternakan Sapi Perah Agro Base, Primkopad Kartika Wijaya Kusuma Mandiri. Balai Latihan Ketrampilan (BLK) Subditbinsiaplurja Ditajenad Bekasi. Materi penelitian 5 ekor sapi Friesian Holstein (HF) laktasi kedua, konsentrat, hijauan, musik, air, dan cairan antiseptik. Alat-alat yang digunakan kandang, tempat ransum, tempat air minum, timbangan digital kapasitas $100 \mathrm{~kg}$, kotak musik, ember plastik, timbangan kapasitas $5 \mathrm{~kg}$, serok, sekop, Hand Trolley. Setiap perlakuan diulang 5 kali.

\section{Analisis Data}

Data dianalis dengan sidik ragam mengacu pada Steel dan Torrie (1991), apabila terdapat pengaruh perlakuan dilanjutkan dengan Uji Jarak Berganda Duncan's.

\section{HASIL DAN PEMBAHASAN}

\section{Pengaruh Musik terhadap Konsumsi Ransum}

Konsusi ransum (kg/ekor) dihitung dengan cara menimbang ransum yang diberikan setiap hari dikurangi ransum yang tersisa, pada hari berikutnya dijumlahkan selama percobaan kemudian dirataratakan. Rataan konsumsi ransum pada masingmasing perlakuan selama penelitian dapat dilihat pada Tabel 1.
Dari Tabel 1 dapat dilihat rataan konsumsi ransum secara berurutan dari yang tertinggi sampai terendah diperoleh dari perlakuan M3 (38,66 kg/ekor), M1 (38,60 kg/ekor), M0 (38,01 kg/ekor), dan M2 (37,65 kg/ekor). Guna mengetahui pengaruh perlakuan terhadap konsumsi ransum, maka dilakukan analisis sidik ragam. Hasil analisis memperlihatkan bahwa perlakuan berpengaruh sangat nyata $(\mathrm{P}<0,01)$ terhadap konsumsi ransum. Untuk mengetahui perbedaan antar perlakuan dilanjutkan dengan Uji Jarak Berganda Duncan's yang hasilnya dapat dilihat pada Tabel 2 .

Hasil uji jarak berganda Duncan's pada Tabel menunjukkan konsumsi ransum M2 berbeda nyata dengan M0 sedangkan M2 berbeda nyata dengan M1 dan M3, demikian juga M0 berbeda nyata dengan M1 dan M3, namun M1 berbeda tidak nyata dengan M3. Konsumsi ransum yang rendah pada M2 diduga musik jazz yang dierdengarkan pada sapi membuat mood sapi terganggu sehingga merasa kurang nyaman dan akan mempengaruhi konsumsi ransum.

Hal ini sesuai dengan pendapat Anonim (2016 ${ }^{\mathrm{d}}$ ), bahwa karakter dari musik jazz cenderung berontak sekalipun dibawakan dengan lembut, sehingga kurang nyaman untuk didengar dan membuat sapi stress. Sejalan dengan pendapat Amalia (2015), bahwa ternak yang mengalami ketidaknyaman di lingkungannya berdampak pada penurunan konsumsi ransum yang disebabkan oleh tingginya hormon kortisolkreatinin. Sientje (2003) bahwa stress yang dipengaruhi oleh lingkungan akan berdapak pada penurunan nafsu makan sapi.

Konsumsi ransum M1 dan M3 nyata lebih besar jumlahnya dari M0. Hal ini diduga kedua jenis musik ini merupakan jenis musik yang lembut sehingga sapi merasa nyaman dan terjadi peningkatan konsumsi ransum karena rasio kortisol-kreatinin lebih rendah. Sejalan dengan pendapat Anonim $\left(2016^{\mathrm{d}}\right)$, bahwa musik tradisional dan musik klasik merupakan musik

Tabel 2. Hasil uji jarak berganda Duncan's pengaruh perlakuan terhadap konversi ransum, rataan produksi susu, konsumsi ransum

\begin{tabular}{cccc}
\hline \hline Perlakuan & Rataan Konversi Ransum & Rataan Produksi Susu (kg) & $\begin{array}{c}\text { Rataan Konsumsi } \\
\text { Ransum }(\mathrm{kg})\end{array}$ \\
\hline M2 & $5,12^{\mathrm{a}}$ & $4,97^{\mathrm{a}}$ & $37,65^{\mathrm{a}}$ \\
M0 & $5,43^{\mathrm{a}}$ & $6,41^{\mathrm{b}}$ & $38,01^{\mathrm{b}}$ \\
M1 & $5,98^{\mathrm{a}}$ & $7,18^{\mathrm{c}}$ & $38,60^{\mathrm{c}}$ \\
M3 & $7,56^{\mathrm{b}}$ & $7,18^{\mathrm{c}}$ & $38,66^{\mathrm{c}}$ \\
\hline
\end{tabular}

Keterangan: Huruf yang berbeda menunjukkan berbeda nyata 
Tabel 3. Rataan produksi susu pada masing-masing perlakuan selama penelitian

\begin{tabular}{ccccc}
\hline \hline \multirow{2}{*}{ Ulangan } & \multicolumn{3}{c}{ Perlakuan $(\mathrm{kg})$} \\
\cline { 2 - 5 } & M0 & M1 & M2 \\
\cline { 2 - 5 } 1 & 6,01 & 8,43 & 4,54 & 7,99 \\
2 & 5,94 & 6,51 & 5,01 & 8,56 \\
3 & 7,36 & 7,21 & 5,1 & 6,81 \\
4 & 6,24 & 6,69 & 4,4 & 7,81 \\
5 & 6,51 & 7,04 & 5,81 & 38,11 \\
\hline Jumlah & 32,06 & 35,88 & 24,86 & 7,66 \\
\hline Rataan & 6,41 & 7,18 & 4,97 & \\
\hline
\end{tabular}

yang memiliki harmon yang sederhana dan cenderung lembut sekalipun dibawakan dengan keras sehingga sapi merasa nyaman dan berdampak pada peningkatan nafsu makan sapi.

Konsumsi ransum M1 dan M3 berbeda tidak nyata, menunjukkan bahwa memperdengarkan musik tradisional dan klasik pada sapi tidak begitu berpengaruh terhadap jumlah konsumsi ransum walaupun ada perbedaan namun perbedaannya hanya sedikit. Hal ini diduga kedua jenis musik ini samasama mempunyai irama yang lembut dan dapat membuat sapi menjadi tenang. Sesuai pendapat Sugeng (2001), faktor-faktor yang mempengaruhi konsumsi ransum adalah genetik dan lingkungan.

\section{Pengaruh Musik terhadap Produksi Susu}

Produksi susu (kg/ekor) produksi susu dihitung dengan cara menimbang susu menggunakan timbangan digital. Rataan produksi susu pada masingmasing perlakuan selama penelitian pada Tabel 3.

Dari Tabel 3 dapat dilihat rataan produksi susu secara berurutan dari yang tertinggi sampai terendah dari perlakuan. M3 (7,66 kg/ekor/hari), M1 (7,18 kg/ekor/hari), M0 (6,41 liter/ekor/hari), dan M2 (4,97 $\mathrm{kg}$ /ekor/hari). Rata-rata produksi susu pada penelitian ini berkisar antara 4,97 $\mathrm{kg}-7,66 \mathrm{~kg}$, produksi susu yang dihasilkan masih jauh dari standar produksi. Menurut Siregar (1995), menyatakan bahwa produksi susu yag ideal antara 15-30 liter/ekor/hari. Kondisi ini mungkin dipengarui oleh lingkungan kurang nyaman yang membuat sapi merasa stress.

Guna mengetahui pengaruh perlakuan terhadap produksi susu, maka dilakukan analisis sidik ragam. Hasil analisis memperlihatkan bahwa perlakuan berpengaruh sangat nyata $(\mathrm{P}<0,01)$ terhadap produksi susu. Untuk mengetahui perbedaan antar perlakuan dilanjutkan dengan uji jarak berganda Dunan's yang hasilnya dapat dilihat pada Tabel 4.

Konversi Ransum = Jumlah ransum dikonsumsi $(\mathrm{kg}) /$ Produksi susu $(\mathrm{kg})$

Hasil Uji Jarak Berganda Duncan's pada Tabel 2 menunjukkan produksi susu M2 berbeda nyata dengan M0 sedangkan M2 berbeda nyata dengan M1 dan M3. Demikian juga M0 berbeda nyata dengan M1 dan M3, namun M1 berbeda tidak nyata dengan M3. M2 menghasilkan produksi susu paling rendah dibandingkan dengan M0, M1 dan M3.
Hal ini diduga musik jazz memiliki harmoni yang rumit, memiliki tonalitas yang luas dan sering terjadi modulasi sehingga sapi yang diperdengarkan jenis musik ini akan merasa tidak nyaman, dan mempengaruhi pelepasan hormon yang berakibat pada produksi susu sedikit. Sesuai pendapat Blakely and Blade (2008), bahwa kondisi lingkungan yang tidak nyaman akan mempengaruhi pelepasan hormon adrenalin dan kelenjar pituitary melalui stimulasi terhadap hypothalamus. Hormon adrenalin menyebar kedalam aliran darah terutama ke ambing, otot ambing tegang sehingga produksi susu sedikit.

Produksi susu M1 dan M3 nyata lebih besar jumlahnya dari M0, hal ini diduga musik yang diperdengarkan pada sapi M1 dan M3 memberikan rasa nyaman pada sapi seingga mempengaruhi pelepasan hormon oxytocin yang lebih banyak dibandingkan dengan sapi yang tidak diperdengarkan musik (M0). Sejalan dengan pendapat Blakely and Blade (2008), bahwa kondisi lingkungan yang nyaman akan mempengaruhi pelepasan hormon oxytocin dari kelenjar pituitary melalui stimulasi terhadap hypotalamus. Hormon oxytocin akan menyebar ke dalam aliran darah terutama ke ambing, sehingga otot ambing tegang dan produksi susu lebih banyak.

M1 berbeda tidak nyata dengan M3, menunjukkan bahwa memperdengarkan musik tradisional dan klasik pada sapi tidak begitu berpengaruh teradap jumlah produksi susu walaupun ada perbedaan namun perbedaannya hanya sedikit. Hal ini diduga kedua jenis musik ini sama-sama mempunyai irama yang lembut dan dapat membuat sapi menjadi tenang.

\section{Pengaruh Musik terhadap Konversi Ransum}

Konversi ransum dihitung dengan cara membagi jumlah ransum yang dikonsumsi selama percobaan di bagi dengan produksi susu selama percobaan. Rataan konversi ransum pada masing-masing perlakuan selama penelitian pada Tabel 4.

Dari Tabel 4 dapat dilihat rataan konversi ransum secara berurutan dari terendah sampai tertinggi diperoleh dari perlakuan M3 $(5,12)$, M1 $(5,54)$, M0 $(5,98)$, M2 $(7,56)$. Guna mengetahui pengaruh perlakuan terhadap konversi ransum dilakukan analisis sidik ragam, hasilnya diketahui bahwa perlakuan berpengaruh sangat nyata $(\mathrm{P}<0,01)$ terhadap konversi ransum. Untuk mengatahui perbedaan antar perlakuan dilakukan Uji Jarak 
Tabel 4. Rataan konversi ransum pada masing-masing perlakuan selama penelitian

\begin{tabular}{ccccc}
\hline \multirow{3}{*}{ Ulangan } & \multicolumn{3}{c}{ Perlakuan } \\
\cline { 2 - 5 } & M0 & M1 & M2 & M3 \\
\hline & & & 7,39 & 4,89 \\
2 & 6,31 & 4,60 & 7,63 & 4,52 \\
3 & 6,46 & 5,93 & 7,48 & 5,96 \\
4 & 5,2 & 5,37 & 8,82 & 5,01 \\
5 & 6,09 & 5,77 & 6,46 & 5,49 \\
\hline Jumlah & 5,82 & 5,50 & 37,78 & 25,6 \\
\hline Rataan & 29,88 & 27,17 & 7,56 & 5,12 \\
\hline
\end{tabular}

Berganda Duncan's yang hasilnya dapat dilihat pada Tabel 2.

Dari Tabel 2 dapat dijelaskan bahwa konversi ransum pada $\mathrm{M} 3$, M1, dan M0 berbeda nyata dengan M2, sedangkan M3 berbeda tidak nyata dengan M1 dan M0. Konversi ransum M2 tinggi dibandingkan dengan M3, M1, dan M0, karena pada M2 efisiensi ransum dan produksi susu rendah. Tingginya konversi ransum menunjukkan produksi susu yang rendah sebagai akibat dari menurunnya efisiensi penggunaan ransum. Sejalan dengan Sudarmono (1993), bahwa konversi ransum sangat dipengaruhi oleh kondisi ternak, daya cerna, jenis kelamin, bangsa, kualitas dan kuantitas ransum, dan lingkungan. Semakin tinggi angka konversi ransum berarti efisiensi ransum kurang baik, sebaliknya semakin rendah efisiensi ransum berarti kualitas ransum semakin baik.

M3 berbeda tidak nyata dengan M1 dan M0, hal ini diduga karena banyaknya ransum yang dikosumsi sesuai dengan produksi susu yang dihasilkan. Sesuai dengan pendapat Rasyaf (1995), konversi ransum adalah banyaknya ransum yang di konsumsi dibandingkan dengan produksi susu yang di hasilkan.

\section{KESIMPULAN}

Berdasarkan hasil dan pembahasan dapat ditarik kesimpulan bahwa musik berpengaruh sangat nyata terhadap performa sapi perah FH laktasi, jenis musik klasik memberikan performa yang optimal pada sapi perah FH laktasi.

\section{DAFTAR PUSTAKA}

Amalia, R. 2015. Musik Sebagai Terapi pada Hewan. http:/www.kompasiana.com/haera ice/musiksebagai-terapi-pada hewan_5510390da333110237ba800f. Diakses pada tanggal 15 Febuari 2017.

Anonim. 2016. Musik Jazz Menurut Pandangan Saya. http://gitarjunior.blogspot.co.id /2015/07/kelebihan-dan-kekurangan-musikjazz.html. Diakses pada tanggal 17 Januari 2017.

Blakely and Blade. 2008. Cara Beternak Sapi Perah. Institut Teknologi Bandung. Bandung.

Leanne. 2001. Researchers at the University of Leicester.

Rasyaf, M. 1995. Beternak Ayam Pedaging. Penebar Swadaya. Jakarta.
Sientje. 2003. Stress Panas pada Sapi Perah Laktasi. Institut Pertanian Bogor. Bogor.

Siregar. 1995. Sapi Perah. Penebar Swadaya, Jakarta.

Steel, R.G.D. dan H. Torrie. 1991. Prnsip Persodur Statistika. Edisi ke-2. Gramedia Pustaka Utama. Jakarta.

Sudarmono. 1993. Tata Usaha Sapi Kereman. Kanisius. Yogyakarta.

Sudono dan Sutardi. 1969. Pedoman Beternak Sapi Perah. Direktorat Peternakan Rakyat. Dirjen Peternakan. Departemen Pertanian. Jakarta.

Sugeng. 2001. Sapi Perah Daerah Tropis. Erlangga. Jakarta. 